\author{
Філіпов
}

(Науковий керівник - доктор сільськогосподарських наук, професор М. I. Федорчук)

Херсонський державний аграрний університет

\title{
ВПЛИВ АГРОТЕХНІКИ ВИРОЩУВАННЯ САФЛОРУ КРАСИЛЬНОГО НА ВОДОСПОЖИВАННЯ І ЙОГО ПРОДУКТИВНІСТЬ В УМОВАХ ПІВДНЯ УКРАЇНИ
}

\section{Рецензент -доктор сільськгосподарських наук, професор С. В. Коковіхін}

У статті наведені результати досліджень впливу агротехнічних прийомів на продуктивність рослин сафлору красильного при його вирощуванні в умовах зрошування півдня Украӥни. В статті наведені результати досліджень впливу агротехнічних прийомів на продуктивність рослин сафлору красильного при його вирощуванні в умовах зрошування півдня України. За результатами досліджень встановлено, щзо при вирощуванні сафлору красильного на зрошуваних землях півдня Украӥни для досягнення рівня врожайності насіння культури в межах 2,0-2,5 m/2а необхідно проводити оранку на глибину 20-22 см, використовувати міжряддя 30 см, сівбу проводити в ранні строки (III декада березня) та вносити мінеральні добрива дозою $N_{60} P_{60}$. Строки сівби та добрива мають найбільшу частку впливу на формування врожайності насіння.

Ключові слова: сафлор красильний, зрочення, строки сівби, водоспоживання, коефіцієнт водоспоживання, врожайність насіння, частка впливу.

Постановка проблеми. Олійні культури мають велике господарське значення завдяки різноманітному та широкому використанню продуктів їх переробки в різних галузях народного господарства.

В групу олійних об'єднують рослини, насіння й плоди яких містять багато жиру (від 20 до $60 \%)$ і є основною сировиною для отримання рослинної олії.

За прогнозами учених-кліматологів на території Європи в 2030 році температура повітря підвищиться приблизно на $1-4{ }^{\circ} \mathrm{C}$. За кількістю опадів прогнозується тенденція до більш посушливої погоди влітку й вологій зимі.

Зміна клімату впливатиме на агрокліматичні умови, а саме на тривалість періоду вегетації, забезпечення рослин вологою, динаміку гідротермічних показників [1-5].

Аналіз основних досліджень і публікацій, у яких започатковано розв'язання проблем. В Україні в теперішній час вирощується понад 50 види лікарських i ароматичних рослин, також їх кількість продовжує збільшуватися за рахунок інт- родукованих об'єктів. Медичній промисловості нашої держави необхідно понад 15 тисяч тонн на рік сухої рослинної лікарської сировини, проте, за рахунок вітчизняних агровиробників вона забезпечена ними лише на 20-30\%.

Чинниками такого негативного становища $\epsilon$ відсутність державної підтримки вирощування лікарських культур, застарілі технології їх вирощування та переробки, розпаювання спеціалізованих господарств по їх вирощуванню тощо.

Існує нагальна потреба розширення посівних площ під лікарськими культурами, підвищення їх врожайності та якості за рахунок розробки й удосконалення технологій вирощування [6-9].

Мета і завдання досліджень. Метою досліджень було встановити динаміку водоспоживання та рівні продуктивності сафлору красильного при вирощуванні на поливних землях півдня України.

Завданням досліджень було встановити динаміку водоспоживання та урожайність насіння сафлору красильного сорту Сонячний залежно від глибини та способу основного обробітку грунту, ширини міжрядь, строків сівби та фону мінерального живлення при вирощуванні в умовах ДП ДГ Інституту рису НААН України с. Антонівка Скадовського району Херсонської області.

Методика досліджень. Польові і лабораторні дослідження 3 сафлором красильним проведені впродовж 2010-2012 pp.

Схемою досліду було передбачено вивчення таких факторів і їх варіантів:

Фактор А - обробіток грунту: мілкий дисковий обробіток на глибину 14-16 см; оранка на глибину 20-22 см.

Фактор В - строки сівби: III декада березня; II декада квітня; III декада квітня.

Фактор C - ширина міжряддя: 30 см; 45 см; 60 см.

Фактор D - дози азотних добрив: без добрив; $\mathrm{N}_{30} ; \mathrm{N}_{60} ; \mathrm{N}_{90}$.

Закладка варіантів досліду проводилась методом рендомізованих розщеплених ділянок з чотириразовим повторенням.

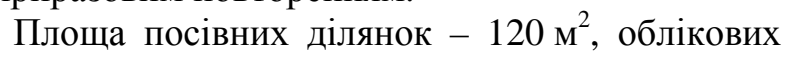


ділянок четвертого порядку - 56 м². Для визначення вологості грунту використовуємо термостатно-ваговий, оснований на вилученні зразків визначеного шару грунту з наступним важенням в лабораторних умовах.

Гідротермічний коефіцієнт визначали за методикою. Сумарне водоспоживання сафлору красильного за весь вегетаційний період та за окремі міжфазні періоди визначали методом водного балансу, коефіцієнт водоспоживання за співвідношенням до врожаю насіння за кожним варіантом.

Результати досліджень. Показники гідротермічного коефіцієнту (ГТК) в роки проведення досліджень істотно змінювались залежно від температурного режиму та кількості атмосферних опадів.

Найвищі значення ГТК зафіксовані у травні 2010 р. (фаза утворення кошика у сафлору красильного) - 0,73, та червні-липні 2011 р. (міжфазний період «цвітіння - налив насіння») 0,48-0,55, відповідно, що мало сприятливий вплив на насіннєву продуктивність рослин.

Найменші значення ГТК були у 2012 р. у фазу цвітіння - дозрівання насіння, що мало негативний вплив на продуктивність рослин і обумовило зниження врожаю насіння.

Сумарне водоспоживання сафлору красильного в роки проведення досліджень істотно змінювалось залежно від фактичних погодних умов та факторів, які були поставлені на вивчення.

У середньому за роки проведення досліджень, щодо впливу основного обробітку грунту на сумарне водоспоживання проявилась слабка перевага оранки над мілким дисковим обробітком, оскільки співвідношення цих показників дорів-

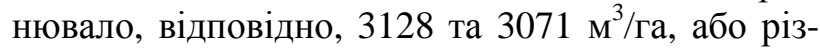
нилось на $1,8 \%$.

По фактору В (ширина міжрядь) встановлено, що найбільше сумарне водоспоживання сформувалось при мінімальній ширині міжрядь 30 см 3091-3145 м³/га. За розширення міжрядь до 45 i $60 \mathrm{~cm}$ зафіксовано незначне зменшення цього показника на 0,71-1,27 \%.

Строки сівби неоднозначно вплинули на величину сумарного водоспоживання. Так, найбільшим даний показник був за раннього строку сівби (III декада березня). Різниця між першим i другим строками була незначною і знаходилася в межах 36-69 м³/га, або 1,1-1,8\%.

Навпаки, при пізньому строці сівби спостерігалось істотне зниження сумарного водоспоживання до 2857-2954 м³/га, або на 8,9-10,3\%.

Максимальне водоспоживання на рівні $3175 \mathrm{~m}^{3} /$ га, в середньому по фактору D, відмічено у варіанті 3 внесенням найбільшої дози азотних i фосфорних добрив $\mathrm{N}_{90} \mathrm{P}_{90}$. У цілому використання добрив обумовило слабке підвищення цього показника (на 1,5-3,3 \%).

Найменші значення коефіцієнту водоспоживання, в середньому за 2010-2012 pp., на рівні $1583 \mathrm{~m}^{3} /$ т були за умов використання оранки за міжрядь 30 см, сівби в III декаду березня та мінеральному удобренні дозою $\mathrm{N}_{90} \mathrm{P}_{90}$. Отже, різниця між цими варіантами становила 2,7 рази.

У середньому по фактору А (основний обробіток грунту) на ділянках 3 мілким дисковим обробітком спостерігалось зростання коефіцієнту водоспоживання до $2543 \mathrm{~m}^{3} / \mathrm{T}$. За використання оранки даний показник зменшився до 2333 м³/т, або на 8,2 \%.

Сівба сафлору 3 міжряддям 30 см обумовила більш раціональне використання грунтової вологи та формування найменшого коефіцієнту водоспоживання діапазоні від 1855 до $2001 \mathrm{~m}^{3} /$ т. За збільшення міжрядь до 45 і 60 см цей показник збільшився до 2365-3030 м³/т, або на 21,6$34,0 \%$.

Проведення сівби сафлору у ранні строки (III декада березня) дозволило отримати найменший коефіцієнт водоспоживання, який дорівнював у цьому варіанті 1748-2584 м³/т. За умов перенесення сівби на другу-третю декади квітня даний показник істотно збільшився до 1859-3451 м³/т, або на $12,9-21,7 \%$.

Високий рівень підвищення використання грунтової вологи посівами сафлору красильного забезпечили азотні та фосфорні добрива. Так, на неудобрених ділянках даний коефіцієнт водоспоживання дорівнював, у середньому по фактору D, $2801 \mathrm{~m}^{3} / \mathrm{T}$, а за внесення добрив дозами $\mathrm{N}_{30} \mathrm{P}_{30}-\mathrm{N}_{90} \mathrm{P}_{90}$ відмічено його зниження до 2089$2332 \mathrm{~m}^{3} / \mathrm{T}$, або на $16,7-25,4 \%$.

Показники врожайності сафлору красильного в середньому за вологозабезпеченням 2010 р. коливались в межах від 0,66 т/га за сполучення таких факторів і варіантів: дисковий обробіток грунту на глибину 14-16 см, міжряддя $60 \mathrm{~cm}$, пізній строк сівби (III декада квітня) та без внесення мінеральних добрив до 2,38 т/га - за взаємодії оранки, міжряддях 30 см, строці сівби в III декаду березня та внесення мінеральних добрив дозою $\mathrm{N}_{90} \mathrm{P}_{90}$.

У вологому 2011 р. внаслідок сприятливих погодних умов відмічено стале зростання врожайності насіння сафлору в середньому по факторах в 1,1-1,6 рази.

Різниця по фактору А (обробіток грунту) між оранкою на глибину 20-22 см (1,94 т/га) та дискуванням на глибину $14-16$ см (1,75 т/га) становила 0,19 т/га, або 9,8\%. 


\section{СТОРІНКА МОЛОДОГО ВЧЕНОГО}

Несприятливі погодні умови 2012 р. навіть за умов використання зрошення негативно вплинули на продуктивність сафлору красильного й обумовили суттєве зниження врожайності культури в усіх варіантах в 1,2-2,2 рази.

Середньофакторіальні показники відображали загальні тенденції, які проявились у роки проведення досліджень. Так, була зафіксована перевага оранки над мілким обробітком грунту, раннього строку сівби, ширини міжрядь $30 \mathrm{~cm}$ та внесення мінеральних добрив дозами $\mathrm{N}_{60} \mathrm{P}_{60}$ та $\mathrm{N}_{90} \mathrm{P}_{90}$ (див. рис.).

У середньому по фактору А стосовно формування врожаю сафлору красильного проявилась перевага оранки над мілким основним обробітком грунту (дискуванням), яка дорівнювала 0,18 т/га, або $11,2 \%$.

Збільшення ширини міжрядь із 30 до 45 i 60 см обумовило зменшення врожайності досліджуваної культури на 0,34-0,53 т/га, або на $18,7-$ $29,0 \%$, що пояснюється біологічними особливо- стями сафлору, зокрема негативною реакцією на широкорядну сівбу.

У роки проведення досліджень врожайність залежала від строків сівби. В середньому по фактору $\mathrm{C}$ цей показник був найбільшим $(1,89$ т/га) за раннього строку сівби (III декада березня). За пізнього строку (III декада квітня) він зменшився до 1,24 т/га.

Також слід підкреслити, що строки сівби змінювались залежно від погодних умов у роки проведення досліджень.

Внесення мінеральних добрив сприяло сталому збільшенню врожайності насіння сафлору красильного на 0,24-0,42 т/га, або на 15,9$24,1 \%$, причому найкращим варіантом виявилась доза добрив $\mathrm{N}_{60} \mathrm{P}_{60}$.

Підвищення фону азотно-фосфорного живлення 360 до 90 кг д.р./га викликало незначне (на 0,02 т/га, або $1,1 \%$ ) зростання продуктивності рослин, але воно було менше за $\mathrm{HIP}_{05}$.

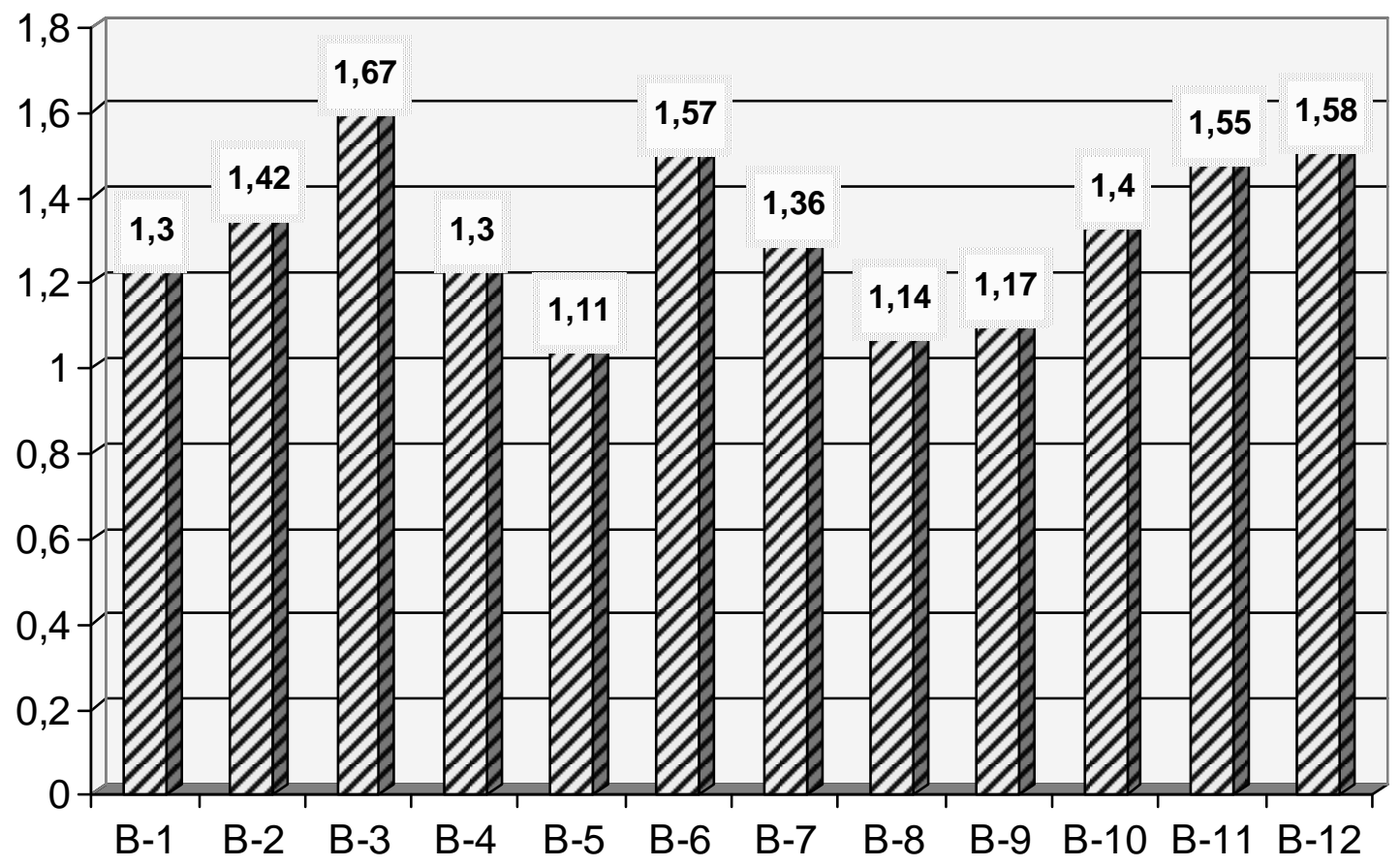

\section{Рис. Середньофакторіальні показники врожайності насіння сафлору красильного залежно від факторів та варіантів:}

B-1 - дисковий обробіток трунту на глибину 14-16 см (фактор A); B-2 - оранка на глибину 20-22 см (фактор A); B-3 - ширина міжряддя 30 см (фактор B); B-4 - ширина міжряддя 45 см (фактор B);

$B-5$ - ширина мізсряддя 60 см (фактор B); B-6 - ранній строк сівби (фактор C); B-7 - середній строк сівби (фактор C); $B-8$ - пізній строк сівби (фактор $C$ ); $B-9$ - без добрив (фактор D);

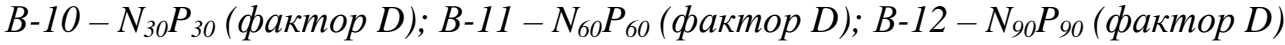


Висновки. Показники водоспоживання сафлору красильного та коефіцієнту водоспоживання культури істотно залежать від погодних умов вегетаційного періоду та агротехнічних заходів, особливо строків сівби. За результатами трирічних досліджень встановлено, що за вирощування сафлору красильного на зрошуваних землях півдня України для досягнення рівня врожайності

\section{БІБЛІОГРАФІЯ}

1. Горнииякий K. C. Заметки об употреблении в народном быту некоторых дикорастущих и разводимых растений Украинской флоры / Горницкий К. С. - Харьков, 1987. - 220 с.

2. Кисничан Л. П. Нетрадиционные и лекарственные растения - источник лекарственного сырья / Л. П. Кисничан, В. Е. Мику // Практическая фитотерапия. - 1999. - №3. - С. 68-71.

3. Олійні культури в Україні: [Навч. посіб.] / За ред. В. Н. Салатенка. - К. : Основа, 2008. $420 \mathrm{c}$.

4. Основы фитомониторинга (мониторинг физиологических процессов в растениях) / [Ильницкий О. А., Бойко М. Ф., Федорчук М. И., Деревянко В. Н.]. - Херсон : Айлант, 2005. - 346 с., ил. насіння культури в межах 2,0-2,5 т/га необхідно проводити оранку на глибину 20-22 см, використовувати міжряддя $30 \mathrm{~cm}$, сівбу проводити в ранні строки (III декада березня) та вносити мінеральні добрива дозою $\mathrm{N}_{60} \mathrm{P}_{60}$. Строки сівби та добрива мають найбільшу частку впливу на формування врожайності насіння.

5. Ahmed M. Effectiveness of Carthamus tinctorius L. in the Restitution of Lipid Composition in Irradiated / A. M. Zahran, M. F. Omran, S. Z. Mansour, N. K. Ibrahim // Rats. Egypt. J. Rad. Sci. Applic. - 2007. - № 20(1). - P. 75-94.

6. Bruneton J. Pharmacognosy, phytochemistry, medicinal plants / J. Bruneton. - Paris : Lavoisier, 1995. - P. 267.

7. Dweck A. C. Nature provides huge range of colour possibilities / A. C. Dweck // Personal Care Magazine. - 2009. - Vol. 5. - P. 61-73.

8. Financing of water infrastructure / Report of the World Panel on Financing Water Infrastructure // Camdessus panel. - GWP, 2003. - 44 p.

9. Hillel D. Salinity Management for Sustainable Irrigation / D. Hillel // AgroTech. - 2000. - P. 34-37. 